\title{
Surface gas pollutants in Lhasa, a highland city of Tibet - current levels and pollution implications
}

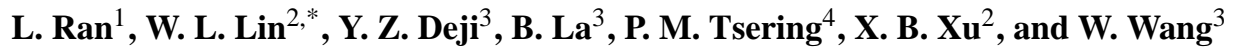 \\ ${ }^{1}$ Key Laboratory of Middle Atmosphere and Global Environment Observation, Institute of Atmospheric Physics, Chinese \\ Academy of Sciences, Beijing 100029, China \\ ${ }^{2}$ Key Laboratory for Atmospheric Chemistry, Chinese Academy of Meteorological Sciences, Beijing 100081, China \\ ${ }^{3}$ Tibet Institute of Plateau Atmospheric and Environmental Science, Lhasa 850000, China \\ ${ }^{4}$ Lhasa Meteorological Service, Lhasa 850000, China \\ *now at: Meteorological Observation Centre, China Meteorological Administration, Beijing 100081, China
}

Correspondence to: W. L. Lin (linwl@cams.cma.gov.cn)

Received: 24 March 2014 - Published in Atmos. Chem. Phys. Discuss.: 12 May 2014

Revised: 29 July 2014 - Accepted: 10 September 2014 - Published: 10 October 2014

\begin{abstract}
Through several years of development, the city of Lhasa has become one of the most populated and urbanized areas on the highest plateau in the world. In the process of urbanization, current and potential air quality issues have been gradually concerned. To investigate the current status of air pollution in Lhasa, various gas pollutants including $\mathrm{NO}_{\mathrm{x}}, \mathrm{CO}, \mathrm{SO}_{2}$, and $\mathrm{O}_{3}$, were continuously measured from June 2012 to May 2013 at an urban site $\left(29.40^{\circ} \mathrm{N}, 91.08^{\circ} \mathrm{E}\right.$, $3650 \mathrm{~m}$ a.s.l.). The seasonal variations of primary gas pollutants exhibited a peak from November to January with a large variability. High mixing ratios of primary trace gases almost exclusively occurred under low wind speed and showed no distinct dependence on wind direction, implying local urban emissions to be predominant. A comparison of $\mathrm{NO}_{2}$, $\mathrm{CO}$, and $\mathrm{SO}_{2}$ mixing ratios in summer between 1998 and 2012 indicated a significant increase in emissions of these gas pollutants and a change in their intercorrelations, as a result of a substantial growth in the demand of energy consumption using fossil fuels instead of previously widely used biomass. The pronounced diurnal double peaks of primary trace gases in all seasons suggested automobile exhaust to be a major emission source in Lhasa. The secondary gas pollutant $\mathrm{O}_{3}$ displayed an average diurnal cycle of a shallow flat peak for about $4-5 \mathrm{~h}$ in the afternoon and a minimum in the early morning. Nighttime $\mathrm{O}_{3}$ was sometimes completely consumed by the high level of $\mathrm{NO}_{\mathrm{x}}$. Seasonally, the variations of $\mathrm{O}_{3}$ mixing ratios displayed a low valley in winter and a peak in spring. In autumn and winter, transport largely
\end{abstract}

contributed to the observed $\mathrm{O}_{3}$ mixing ratios, given its dependence on wind speed and wind direction, while in spring and summer photochemistry played an important role. A more efficient buildup of $\mathrm{O}_{3}$ mixing ratios in the morning and a higher peak in the afternoon was found in summer 2012 than in 1998. An enhancement in $\mathrm{O}_{3}$ mixing ratios would be expected in the future and more attention should be given to $\mathrm{O}_{3}$ photochemistry in response to increasing precursor emissions in this area.

\section{Introduction}

The Tibetan Plateau, with an average altitude of about $4000 \mathrm{~m}$, is the highest plateau in the world. The capital city of Tibet, Lhasa, is one of the most populated and urbanized areas in this region. Lhasa lies on the northern bank of the Lhasa River in the Lhasa River valley, which runs west to east and is surrounded by mountains. There are currently 200 thousand inhabitants and a floating population of nearly 400 thousand within an urban area of about $63 \mathrm{~km}^{2}$. The number of automobiles in Lhasa was already over 150 thousand at the end of 2012.

In Lhasa, gas pollutants including nitrogen oxides $\left(\mathrm{NO}_{\mathrm{x}}=\mathrm{NO}+\mathrm{NO}_{2}\right)$, carbon monoxide $(\mathrm{CO})$, sulfur dioxide $\left(\mathrm{SO}_{2}\right)$ and volatile organic compounds (VOCs) are mainly from automobile exhaust, heating, kitchen, small light industries and incense burning in temples. At a high altitude above 
$3650 \mathrm{~m}$, the absolute content of oxygen in Lhasa is about $68 \%$ of that at the sea level. Incomplete fuel combustion in the low oxygen-containing atmosphere (Chaffin and Ullman, 1994; Bishop et al., 2001; Nagpure et al., 2011), as well as the rapidly increasing vehicles undoubtedly enhances atmospheric pollutants of vehicular origin. These atmospheric pollutants impair the visibility and degrade the air quality. Moreover, the secondary gas pollutant ozone $\left(\mathrm{O}_{3}\right)$ can be generated by its precursors $\mathrm{NO}_{\mathrm{x}}$ and VOCs in the presence of sunlight (e.g., Haagen-Smit, 1952; Haagen-Smit et al., 1953; Seinfeld and Pandis, 1998). Surface $\mathrm{O}_{3}$ pollution is one of the most stubborn and pervasive environmental problems in the world. At a high mixing ratio, $\mathrm{O}_{3}$ is harmful to human health and the ecosystem (Chameides et al., 1994; Jacobson, 2002). With a high production potential of $\mathrm{OH}$ radicals over the Tibetan Plateau, where the solar radiation is strong due to the high altitude as well as the low latitude and the background mixing ratio of ozone is high, the atmosphere in Lhasa was expected to be very photochemically active (Lin et al., 2008). A concern should thereby be raised on the $\mathrm{O}_{3}$ problem, given the increasing emissions of $\mathrm{O}_{3}$ precursors in the process of urbanization.

Most efforts have previously been exerted on exploring the $\mathrm{O}_{3}$ valley and $\mathrm{O}_{3}$ vertical profiles over the Tibetan Plateau by satellite observations (Guo et al., 2012), ozone sondes (Shi et al., 2000; Tobo et al., 2008; Bian et al., 2012) and model simulations (Liu et al., 2003; Tang and Prather, 2012). Investigations on surface trace gases have rarely been reported for Lhasa, the rapidly growing capital city of Tibet (Yu et al., 2001; Zhou et al., 2001; Tang et al., 2002; Dechen et al., 2008). In comparison with many other cities in China (He et al., 2002 and the references therein), air quality in Lhasa was quite fine. The level of air pollutants in Lhasa has never exceeded the national air quality standards according to the reports of the local environment protection bureau. However, with thriving tourism and economy in the process of urbanization, more and more pollutants are expected to be accumulated within the city due to the valley topography. In this paper, an analysis of systematically collected data of surface $\mathrm{O}_{3}, \mathrm{NO}_{\mathrm{x}}, \mathrm{CO}$, and $\mathrm{SO}_{2}$ during 1 year is presented and discussed. The observational site and instruments are described in Sect. 2. An overview of meteorology is given in Sect. 3.1. Seasonal and diurnal variations of the gas pollutants are presented in Sect. 3.2, followed by a discussion on how meteorology could influence the observed mixing ratios of gas pollutants in Sect. 3.3. A possible impact of urbanization on air quality in Lhasa in past decades is discussed in Sect. 4.

\section{Observations}

\subsection{The site}

Lhasa sits in a flat river valley in the Himalaya mountains (Fig. 1a). Located at the bottom of a small basin surrounded

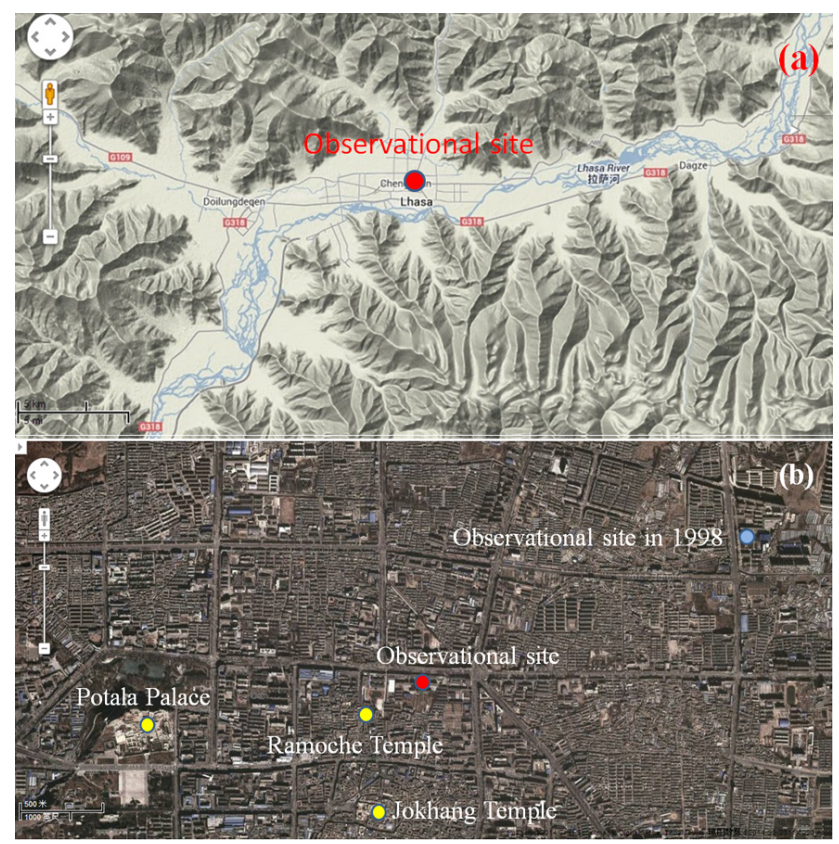

Figure 1. (a) The topography and (b) the urban map of the site and its surrounding area (from Google Maps).

by the Himalaya mountains, Lhasa has an elevation of about $3650 \mathrm{~m}$ and lies in the center of the Tibetan Plateau with the surrounding mountains rising to $5500 \mathrm{~m}$. The Lhasa River (or Kyi Chu), a tributary of the Yarlung Zangbo River, runs through the southern part of the city. The marshlands, mostly uninhabited, are to the north of the city. Ingress and egress roads run east and west.

The observational site $\left(29.40^{\circ} \mathrm{N}, 91.08^{\circ} \mathrm{E}, 3650 \mathrm{~m}\right.$ a.s.l. $)$ for this study is at a meteorological and atmospheric composition monitoring station, located in a residential and commercial area in urban Lhasa (Fig. 1b). The site is about $2 \mathrm{~km}$ east of the famous Potala Palace. There are also another two famous temples (Jokhang Temple and Ramoche Temple) within the surrounding $1 \mathrm{~km}^{2}$ of the site. In addition, measurements of trace gases were also conducted in summer 1998 at a suburban site to the east of the city center $\left(29.65^{\circ} \mathrm{N}, 91.16^{\circ} \mathrm{E}, 3650 \mathrm{~m}\right.$ a.s.l.). This suburban site was located in large areas of farms with sparsely interspersed residency 15 years ago, but now already within the populated areas of Lhasa after its continuous expansion and development.

\subsection{Instruments and data}

Surface trace gases were continuously monitored for 1 year from June 2012 to May 2013, using commercial instruments installed on top of a $20 \mathrm{~m}$ high building at the site. Observations of $\mathrm{CO}$ and $\mathrm{SO}_{2}$ started from August 2012. Missing CO data from 28 April to 16 May 2013 was due to a malfunction of the $\mathrm{CO}$ analyzer. 
A UV photometric analyzer (Model 49C) from Thermo Electron Corporation (TE, USA) was used to determine the $\mathrm{O}_{3}$ mixing ratios. $\mathrm{CO}$ was measured with a gas filter correlation analyzer (TE 48CTL). $\mathrm{SO}_{2}$ was measured with a pulsed fluorescence analyzer (TE 43CTL). EC9841B/ECOTECH nitrogen oxides analyzer with a heated molybdenum $\mathrm{NO}_{2}$ to NO converter and the chemiluminescence technique was used to simultaneously quantify mixing ratios of $\mathrm{NO}$ and $\mathrm{NO}_{\mathrm{x}}$. According to USEPA recommendations on quality assurance and quality control (USEPA, 2008), multipoint calibrations were operated every month using a dynamic gas calibrator (Gascal 1100, Ecotech, Australia) and a zero air supplier (Eco Physics PAG003, Switzerland), together with the standard reference gas mixture ( $\mathrm{NO} / \mathrm{CO} / \mathrm{SO}_{2}$ in $\mathrm{N}_{2}$ ). The $\mathrm{O}_{3}$ analyzer was calibrated using a TE 49CPS calibrator, which is a reference for the WMO regional GAW stations in China and traceable to the WMO NIST standard. Particularly, zero checks for the $\mathrm{CO}$ analyzer were automatically performed every $2 \mathrm{~h}$ to record zero drifts, using the SOFNOCAT 514 oxidation catalyst (Molecular Products Asia Ltd, UK) and a 3-way solenoid valve. Ambient mixing ratios of trace gases were recorded as 1-min averages (ppb).

Meteorological data were obtained from an Automatic Weather Station at the site. Wind speed and wind direction were measured at $10 \mathrm{~m}$ height, reported as 10 -min average wind speed and 10-min smoothing wind direction based on 1-s sampling data for each hour. Other parameters including temperature, relative humidity and precipitation were observed at $1.5 \mathrm{~m}$ height and reported in hourly averages. Cloud amount was recorded four times each day: 00:00, 06:00, 12:00 and 18:00 LT (local time).

At the suburban site, measurements of $\mathrm{O}_{3}, \mathrm{NO}_{2}, \mathrm{CO}$, and $\mathrm{SO}_{2}$ mixing ratios were carried out from June to September 1998 on top of a 3-storey building (Tang et al., 2002). As for $\mathrm{O}_{3}$ and $\mathrm{CO}$, the same measurement principles and similar quality control procedures were used in both 1998 and 2012, with a linear uncertainty of about $2 \% . \mathrm{O}_{3}$ mixing ratios were measured by a UV photometric analyzer (TE 49C), which was calibrated using a TE 49CPS calibrator. CO gas correlation filter (GFC, Advanced Pollution Instruments Inc, USA) with the non-dispersive infrared (NDIR) technique was used to monitor the low level of $\mathrm{CO}$ mixing ratios. Also due to the extremely low level of $\mathrm{NO}_{2}$ and $\mathrm{SO}_{2}$ mixing ratios in Lhasa at that time, the air was sampled for $4170 \mathrm{~min}$ by filter-based samplers every 3 to 4 days. Mixing ratios of $\mathrm{NO}_{2}$ and $\mathrm{SO}_{2}$ were quantified in the laboratory by the DX-500 ion chromatography system (Dionex, USA) and reported in ppb (the lowest detect limits were 0.03 and 0.02 ppb for $\mathrm{SO}_{2}$ and $\mathrm{NO}_{2}$, respectively).

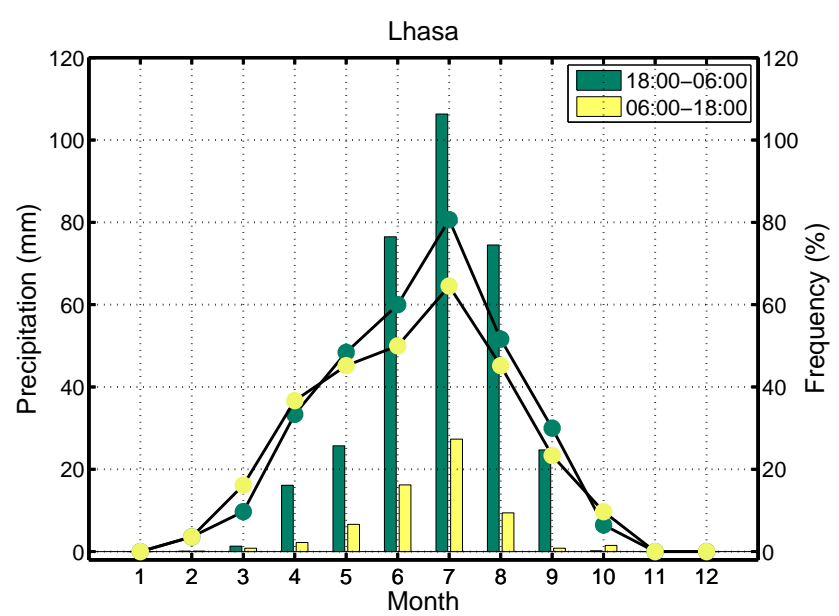

Figure 2. Precipitation (bars) in the daytime (06:00-18:00 LT) and at night (18:00-06:00 LT) from June 2012 to May 2013 in Lhasa. The frequency of precipitation in each month is shown by dots.

\section{Results and discussion}

\subsection{An overview of meteorology}

Situated on the Tibetan Plateau, Lhasa has a very high level of ultraviolet radiation, especially in the summer, due to the high altitude, the low latitude and the tenuous atmosphere (Pu Bu et al., 1997; Ren et al., 1999; Norsang et al., 2009). With strong solar radiation in the daytime, the maximum air temperature could still reach as high as $15.8^{\circ}$ even in the coldest month January, when the average air temperature was below zero and the minimum was $-11.4^{\circ}$. The highest monthly average of $18.1^{\circ}$ and daily maximum of $28.9^{\circ}$ were found in June. The weather in the rainy season from May to September was generally warm, humid and cloudy. Monthly averages of the temperature and relative humidity ranged from $13.3 \pm 5.2$ to $18.1 \pm 4.4^{\circ}$ and from 41 to $60 \%$, respectively. In the rainy season, the precipitation amounted to $368 \mathrm{~mm}$, about $94 \%$ of the total amount in the year (Fig. 2). Despite the large amount of frequently observed precipitation in the rainy season, particularly in summer from June to August, most of the precipitation occurred at night (18:0006:00 LT), accounting for $84 \%$ of the total amount during this period. In the rest of the year, it was usually dry and cloud-free. There was hardly any precipitation from October to March. During this period, around $46 \%$ of the days were clear in the daytime based on the cloud amount, while at night the fraction rose to about $74 \%$. Monthly averages of the temperature and relative humidity ranged from $-0.1 \pm 5.8$ to $10.6 \pm 5.5^{\circ}$ and from 14 to $27 \%$, respectively, in the dry period.

The frequency of wind direction in each season is displayed in Fig. 3 by the wind rose. Wind direction was mainly found in the WSW-WNW and ENE-ESE sectors (Fig. 3a), as a result of the orientation of the Lhasa River valley. The 


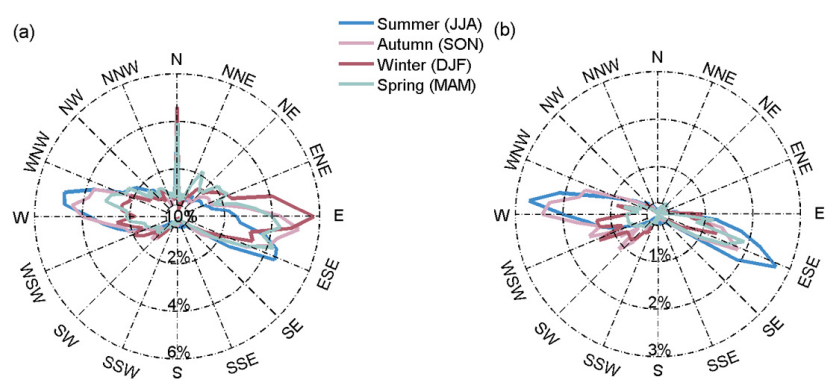

Figure 3. The frequency of wind direction plotted by wind rose for four seasons in Lhasa, (a) with all wind speed, the frequency of calm conditions is given in the center circle, (b) with wind speed above $2 \mathrm{~m} \mathrm{~s}^{-1}$.

mountains to the north and south of the city significantly inhibited winds in these directions, especially those with a wind speed above $2 \mathrm{~m} \mathrm{~s}^{-1}$. The frequency of northerly winds was though comparable with that of easterly or westerly winds, the wind speed of northerly winds was exclusively under $2 \mathrm{~m} \mathrm{~s}^{-1}$ (Fig. 3b). The observed 10-min average wind speed was mostly smaller than $2 \mathrm{~m} \mathrm{~s}^{-1}$ (close to $65 \%$ ), with the annual average occurrence of calm conditions to be about $10 \%$ and the frequency of wind speed larger than $2 \mathrm{~m} \mathrm{~s}^{-1}$ around $25 \%$. High wind speed was usually observed in the afternoon in summer and autumn.

\subsection{Seasonal and diurnal variations of gas pollutants}

Monthly averages of $\mathrm{O}_{3}, \mathrm{O}_{\mathrm{x}}\left(\mathrm{O}_{3}+\mathrm{NO}_{2}\right), \mathrm{NO}, \mathrm{NO}_{\mathrm{x}}, \mathrm{CO}$, and $\mathrm{SO}_{2}$ mixing ratios are displayed in Fig. 4. Ozone and total oxidant $\mathrm{O}_{\mathrm{x}}$ exhibited similar seasonal variations, with the peak in spring and the low valley in winter. The maximum monthly mean mixing ratios of $\mathrm{O}_{3}$ and $\mathrm{O}_{\mathrm{x}}$ were observed in May as $56.8 \pm 10.1 \mathrm{ppb}$ and $70.1 \pm 10.6 \mathrm{ppb}$, respectively. The highest monthly $\mathrm{O}_{3}$ average mixing ratio observed in Lhasa was slightly higher than that of $54.8 \pm 18.1 \mathrm{ppb}$ observed in June 2007 at a rural site Gucheng, which was thought to have good regional representativeness of the North China Plain, one of the most polluted regions in the world (Lin et al., 2009). The highest hourly $\mathrm{O}_{3}$ mixing ratio of $90.6 \mathrm{ppb}$ in Lhasa was also observed in May, while in another more industrialized high altitude urban area, the Mexico City, hourly ozone mixing ratios could easily exceeded 120 ppbv (Molina and Molina, 2004; Lei et al., 2008). The lowest monthly mean mixing ratios of $\mathrm{O}_{3}$ and $\mathrm{O}_{\mathrm{x}}$ were $22.9 \pm 4.0 \mathrm{ppb}$ in December and $39.5 \pm 4.1 \mathrm{ppb}$ in January.

The air in Lhasa was mostly polluted from November to January with respect to the levels of $\mathrm{SO}_{2}(2.72 \pm 2.05 \mathrm{ppb})$ and $\mathrm{O}_{3}$ precursors $\mathrm{NO}_{\mathrm{x}}(29.58 \pm 16.16 \mathrm{ppb})$ and $\mathrm{CO}$ $(570 \pm 300 \mathrm{ppb})$, possibly as a result of slowed removal processes, increased emissions and accumulation within the boundary layer. The mixing ratios of $\mathrm{SO}_{2}$ and $\mathrm{O}_{3}$ precursors during the most polluted season in Lhasa were at least less than half of that in urban Mexico City based on yearly aver- ages (Molina and Molina, 2004; Stephens et al., 2008), since Lhasa is less populated and industrialized than the Mexico City. In the rest of the year, $\mathrm{SO}_{2}, \mathrm{CO}$, and $\mathrm{NO}_{\mathrm{x}}$ averaged $0.77 \pm 0.61 \mathrm{ppb}, 363 \pm 94 \mathrm{ppb}$, and $17.10 \pm 6.19 \mathrm{ppb}$, respectively. The highest daily mean mixing ratios of $\mathrm{SO}_{2}, \mathrm{CO}$, $\mathrm{NO}$, and $\mathrm{NO}_{\mathrm{x}}$ were, respectively, 14.50, 2097, 74.12, and 97.2 ppb, occurring on 18 December 2012.

Diurnal variations of $\mathrm{O}_{3}, \mathrm{Ox}, \mathrm{NO}, \mathrm{NO}_{\mathrm{x}}, \mathrm{CO}$, and $\mathrm{SO}_{2}$ mixing ratios in spring (March-May), summer (June-August), autumn (September-November) and winter (DecemberFebruary) are plotted in Fig. 5. The diurnal cycle of $\mathrm{O}_{3}$ mixing ratios averagely exhibited a shallow flat peak for about $4-5 \mathrm{~h}$ in the afternoon and a minimum in the early morning throughout the year. $\mathrm{O}_{3}$ mixing ratios reached about $57 \mathrm{ppb}$ in the afternoon (12:00-17:00 LT) in spring, when meteorological conditions favored $\mathrm{O}_{3}$ photochemical production. In summer and autumn, the $\mathrm{O}_{3}$ mixing ratios averaged over the afternoon were close to $48 \mathrm{ppb}$, and the lowest average value was observed in winter as $37 \mathrm{ppb}$. Nighttime $\mathrm{O}_{3}$ mixing ratios were much higher in spring and summer than in autumn and winter, which was mainly attributed to a large amount of $\mathrm{NO}$ emissions from heating and the more stable surface layer under relatively lower wind speed in the cold weather (see Fig. 3). As for other gas pollutants, pronounced double peaks in the diurnal variations could be clearly identified in all seasons. The morning peaks (around 07:00 LT) and the evening peaks (around 20:00 LT) resulted from enhanced traffic emissions in the rush hours as well as the diurnal variations of the boundary layer. Mixing ratios of $\mathrm{O}_{3}$ precursors and $\mathrm{SO}_{2}$ were found to be highly variable during the rush hours and the night, especially in autumn and winter. The ceasing of photochemical reactions and the formation of the boundary layer should be responsible for a stronger evening peak compared to the morning peak.

\subsection{Influences of meteorology on gas pollutants}

As for the secondary gas pollutant $\mathrm{O}_{3}$, meteorology could exert an influence on the ambient mixing ratios by transport and accelerating or decelerating the photochemical reactions. In spring and summer, the weather was generally warm and sunny in the daytime, favoring $\mathrm{O}_{3}$ photochemical production. No distinct dependence of $\mathrm{O}_{3}$ mixing ratios on wind speed and wind direction was found in spring and summer (figure not shown here), suggesting that $\mathrm{O}_{3}$ photochemistry might play an important role in the observed mixing ratios. Although ozone photochemical production should be higher in summer than in spring, the average $\mathrm{O}_{3}$ mixing ratio was lower in summer than in spring as mentioned in Sect. 3.2. This suggests that the large-scale background of $\mathrm{O}_{3}$ in spring (Monks, 2000) also plays a role in the observed surface $\mathrm{O}_{3}$ in Lhasa. Under the influence of the Asian summer monsoon, more precipitation occurs and inhibits the formation and accumulation of $\mathrm{O}_{3}$, since precipitation could efficiently remove $\mathrm{O}_{3}$ and its precursors from the troposphere (Ma et 
Lhasa,Tibet
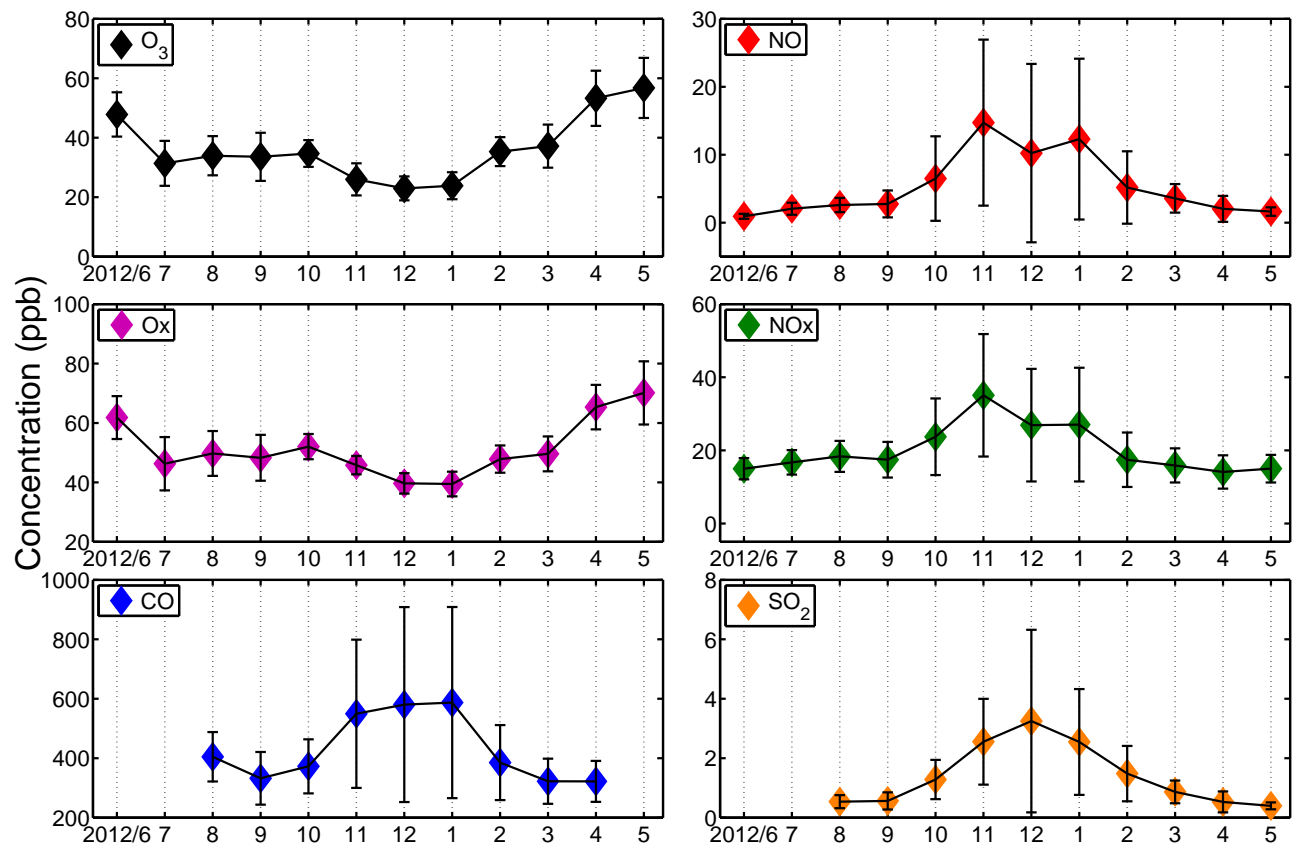

Figure 4. Monthly averages (markers) and standard deviation (black lines) of gas pollutants in Lhasa from June 2012 to May 2013.

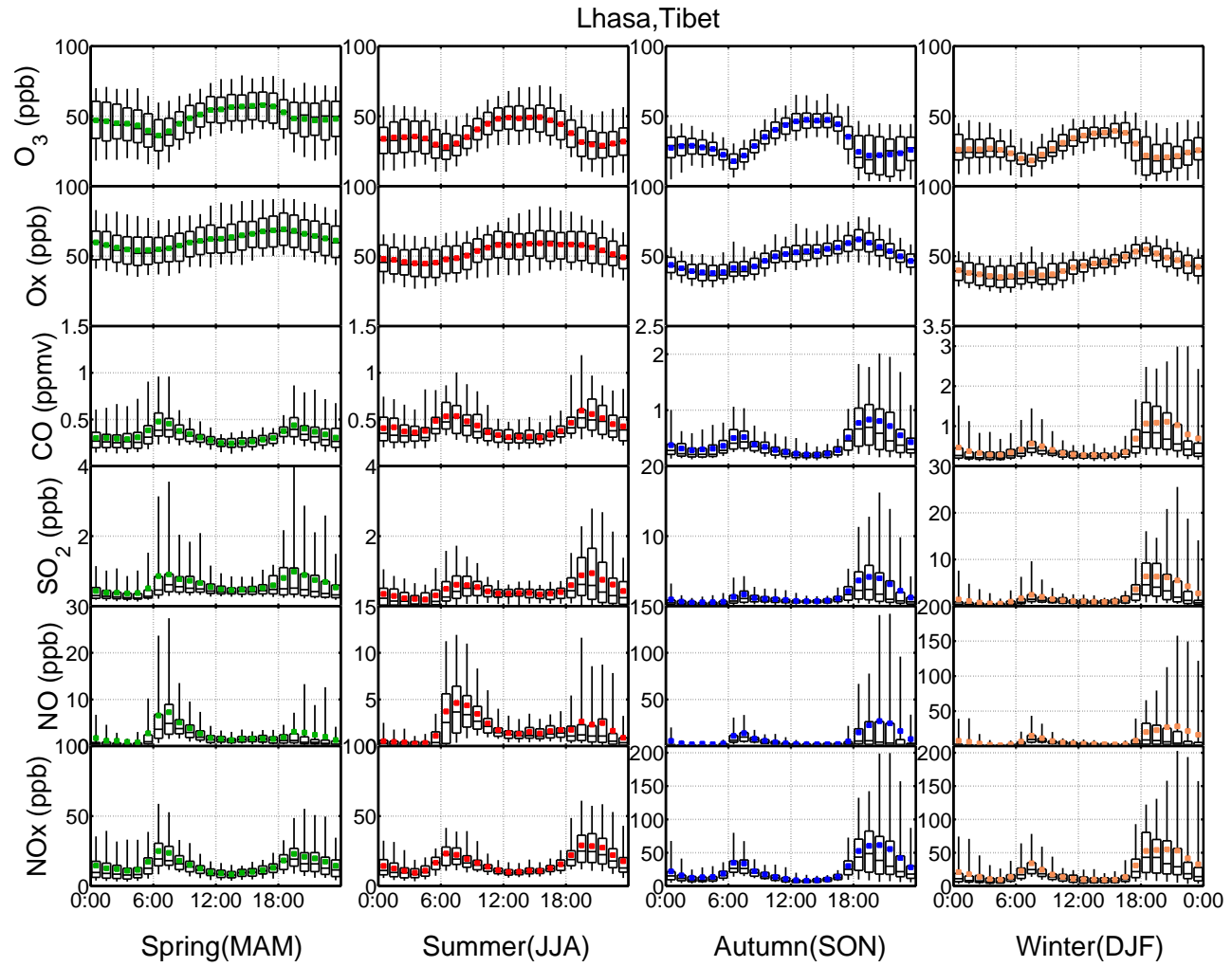

Figure 5. Average diurnal variations of $\mathrm{O}_{3}, \mathrm{O}_{\mathrm{x}}, \mathrm{CO}, \mathrm{SO}_{2}, \mathrm{NO}$, and $\mathrm{NO}_{\mathrm{x}}$ mixing ratios in four seasons (during June 2012 and May 2013) in Lhasa. Colored markers represent hourly mean mixing ratios. Black boxes and whiskers indicate the 5th, 25th, 50th, 75th and 95th percentiles. 
Table 1. Hourly average mixing ratios of the trace gases under polluted conditions (defined in this paper) and non-polluted conditions. The exceedance frequency $(\%)$ based on hourly averages is given in the brackets.

\begin{tabular}{lllllllll}
\hline & \multicolumn{2}{c}{$\mathrm{O}_{3}(\mathrm{ppb})$} & \multicolumn{2}{c}{$\mathrm{NO}_{\mathrm{x}}(\mathrm{ppb})$} & \multicolumn{2}{c}{$\mathrm{CO}(\mathrm{ppb})$} & \multicolumn{2}{c}{$\mathrm{SO}_{2}(\mathrm{ppb})$} \\
\cline { 2 - 8 } & Polluted & Non-P & Polluted & Non-P & Polluted & Non-P & Polluted & Non-P \\
\hline Spring & $83.8(1.6)$ & 48.3 & $67.42(2.0)$ & 12.43 & $1187(0.8)$ & 322 & - & 0.61 \\
Summer & $85.5(0.1)$ & 37.8 & $62.72(1.7)$ & 14.43 & $1273(1.3)$ & 407 & - & 0.46 \\
Autumn & - & 31.6 & $99.38(10.9)$ & 14.85 & $1567(6.5)$ & 332 & $15.34(1.9)$ & 1.19 \\
Winter & - & 27.6 & $101.21(10.8)$ & 13.76 & $1968(10.4)$ & 345 & $18.31(3.9)$ & 1.53 \\
\hline
\end{tabular}

al., 2014). Occasionally, $\mathrm{O}_{3}$ pollution events could be observed at night in spring when easterly winds above $2 \mathrm{~m} \mathrm{~s}^{-1}$ prevailed for several hours and brought in $\mathrm{O}_{3}$-rich air. A pollution event is defined here as the hourly average mixing ratio exceeding $80 \mathrm{ppb}$ for $\mathrm{O}_{3}, 50 \mathrm{ppb}$ for $\mathrm{NO}_{\mathrm{x}}, 1000 \mathrm{ppb}$ for $\mathrm{CO}$ and $10 \mathrm{ppb}$ for $\mathrm{SO}_{2}$. The average mixing ratios of the trace gases under the thus-defined polluted conditions, and nonpolluted conditions are accordingly given in Table 1 . The exceedance frequency $(\%)$ based on hourly averages is given in the brackets. The occurrence of $\mathrm{O}_{3}$ pollution events were only found in spring and summer, majorly in the afternoon in spring. In autumn and winter, the transport process instead of the photochemical process probably made a major contribution to the ambient $\mathrm{O}_{3}$ mixing ratios. On average, the $\mathrm{O}_{3}$ mixing ratios were found to be nearly $10 \mathrm{ppb}$ higher in the SW-NW sector than in other directions. With increasing wind speed, the mixing ratios of $\mathrm{O}_{3}$ also slightly increased.

The dependence of primary gas pollutants on wind followed a similar pattern throughout the year (figure not shown here). The ambient mixing ratios of $\mathrm{NO}_{\mathrm{x}}, \mathrm{CO}$, and $\mathrm{SO}_{2}$ were quite high under low wind speed (smaller than $2 \mathrm{~m} \mathrm{~s}^{-1}$ ) and decreased sharply as the wind speed increased. There was a slight dependence of $\mathrm{NO}_{\mathrm{x}}, \mathrm{CO}$, and $\mathrm{SO}_{2}$ mixing ratios on wind direction only under low wind speed, showing a higher level in the NW-N sector, indicating that local emissions of automobiles and heating as well as incense burning to be dominant in Lhasa. High mixing ratios of primary gas pollutants were mainly observed in autumn and winter (Table 1). Almost $90 \%$ of the pollution episodes occurred at calm night in autumn and winter, when chemical transformation of primary gases were slowed down and the accumulation was favored. The highest hourly mixing ratios of $\mathrm{SO}_{2}, \mathrm{CO}, \mathrm{NO}$, and $\mathrm{NO}_{\mathrm{x}}$ occurred near midnight in December or January, and were $63.44,8511,412.36$, and $468.43 \mathrm{ppb}$, respectively. The hourly maxima of $\mathrm{CO}$ mixing ratios in Lhasa were almost comparable with that at Gucheng and Wuqing, two sites well representative of the regional pollution in the North China Plain (Lin et al., 2009; Xu et al., 2011). The occurrence frequency of hourly CO mixing ratios above $3000 \mathrm{ppb}$, which could approximately be taken as the average level in winter in the North China Plain, ranged from 7 to $16 \%$. The hourly maxima of $\mathrm{NO}$ and $\mathrm{NO}_{\mathrm{x}}$ mixing ratios were much higher than that of 202 and $300 \mathrm{ppb}$ in the megacity of Beijing in the heating season from November 2007 to March 2008, despite that the averages in Lhasa were about $30 \mathrm{ppb}$ lower during that period (Lin et al., 2011). Hourly $\mathrm{NO}_{\mathrm{x}}$ mixing ratios above the average level of $60 \mathrm{ppb}$ observed during the heating season in Beijing accounted for around $70 \%$ of the period from October to February in Lhasa. The level of $\mathrm{SO}_{2}$ mixing ratios in Lhasa was much lower, compared to a mixing ratio of several ppb in summer to tens of ppb in winter in the North China Plain (Lin et al., 2012). The occurrence frequency of hourly $\mathrm{SO}_{2}$ mixing ratios above the average level of $30 \mathrm{ppb}$ in the heating season in Beijing ranged from 3 to $6 \%$. Generally, primary gas pollution has been quite noticeable in Lhasa in the cold season.

\subsection{Impacts of urbanization on air pollution}

Lhasa has undergone remarkable changes in the process of urbanization in the past decades. The area of the city has currently been enlarged almost twice of that as $34 \mathrm{~km}^{2}$ in 1998 , when the measurements of trace gases at the suburban site took place. The permanent and floating population has been explosively expanding, as well as the number of automobiles. According to the municipal statistical data, the permanent population in Lhasa was only 43 thousand in 1998, about one quarter of that now. The number of tourists has dramatically increased from 200 thousand per year in 1998 to 6.5 million in 2012. Compared to over 150 thousand automobiles in 2012, the number was less than 10 thousand in 1998. The gross domestic product of Lhasa amounted to 2.9 and 26.2 billion RMB in 1998 and 2012, respectively. The fast development during urbanization has led to a substantial growth in the demand of energy consumption. As a result, the urban heat island intensity of Lhasa has increased from $1.8^{\circ}$ in 1998 to $2.2^{\circ}$ in 2012 based on the meteorological data (Tsering et al., 2014). Meanwhile, the energy structure in Lhasa has been through a significant change. In 1998, biomass such as cow dung, fagots and leaves were widely used by local residents. Petroleum products and coal only contribute a negligible portion to the fuel mix in this region. Nowadays, however, fossil fuel has become an important component of consumed energy sources. Along with the enhanced energy consumption and the transformation of fuel mix, the level of atmospheric 


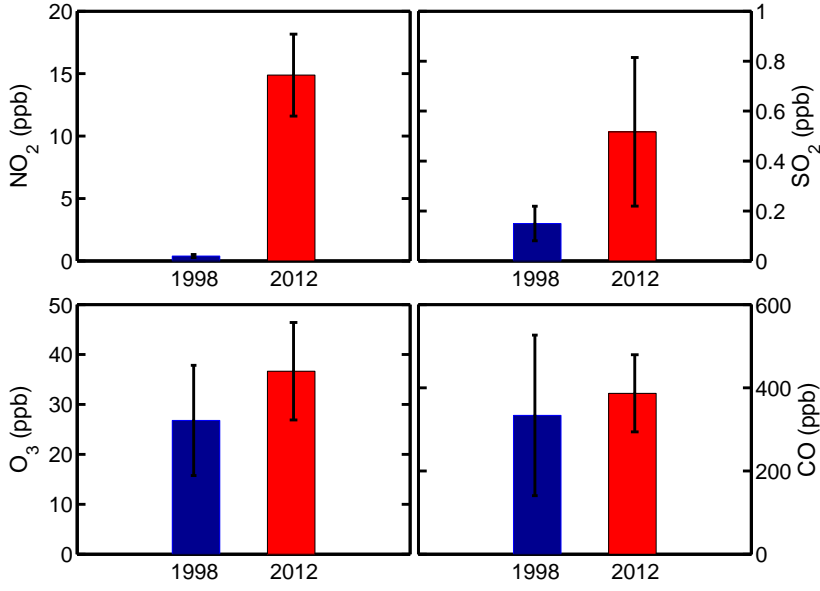

Figure 6. Comparisons of the average mixing ratios (bars) of $\mathrm{NO}_{2}$, $\mathrm{SO}_{2}, \mathrm{O}_{3}$, and $\mathrm{CO}$ during June and September between 1998 and 2012. The black line gives the standard deviation.

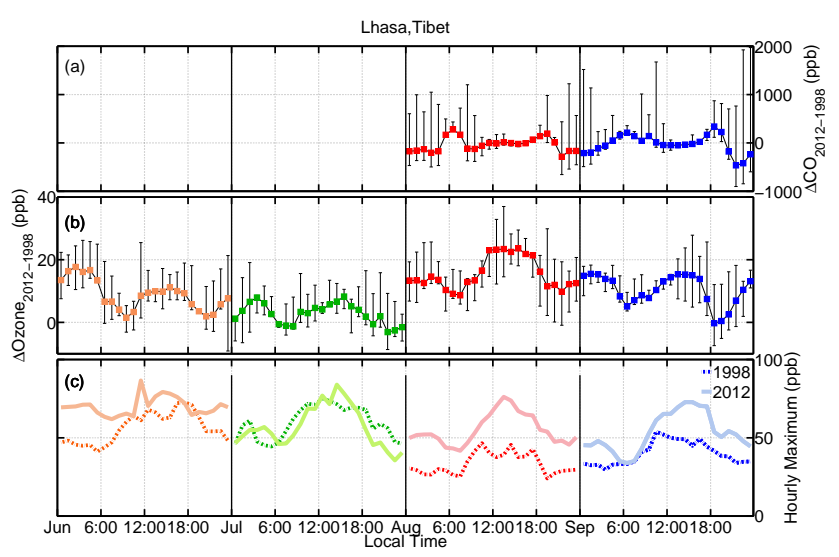

Figure 7. (a) The differences in the average diurnal variations of CO mixing ratios between 1998 and 2012 in Lhasa, the dots represent monthly mean values, the black lines denote the minimum and maximum of the differences; (b) for $\mathrm{O}_{3}$, the markers are the same as that in (a); (c) the maximum $\mathrm{O}_{3}$ mixing ratio for each hour in each month, the darker color represents the values in 1998, whereas the lighter color represents the values in 2012.

pollutants has risen year by year. Undoubtedly, this would give rise to notable environment problems in Lhasa.

A comparison was made between the levels of $\mathrm{NO}_{2}, \mathrm{SO}_{2}$, $\mathrm{CO}$, and $\mathrm{O}_{3}$ measured during June and September, respectively, in 1998 and 2012 (Fig. 6). Generally, it was found that the current average level of $\mathrm{NO}_{2}$ in summertime was about $15 \mathrm{ppb}$, almost 40 times of $\mathrm{NO}_{2}$ mixing ratios 15 years ago. During the sampling period in 1998 , measured $\mathrm{NO}_{2}$ mixing ratios never exceeded $1 \mathrm{ppb}$. In contrast, the lowest daily mean mixing ratio of $\mathrm{NO}_{2}$ was around $9 \mathrm{ppb}$ and the highest value was close to $27 \mathrm{ppb}$ in summer 2012, clearly indicating a marked increase in $\mathrm{NO}_{\mathrm{x}}$ emissions, which are largely from vehicular exhaust in urban Lhasa. A comparatively smaller change has been observed in $\mathrm{SO}_{2}$ mixing ratios, with an increase in the average level of $\mathrm{SO}_{2}$ from about 0.15 to $0.5 \mathrm{ppb}$. The highest hourly $\mathrm{SO}_{2}$ average observed in summer 2012 was around $5 \mathrm{ppb}$. In Lhasa, $\mathrm{SO}_{2}$ is mostly from coal burning and less from vehicular exhaust and incense burning. The demand of coal has taken a relatively slower pace than that of petroleum as fuel for automobiles. Incense burning, which gives off $\mathrm{SO}_{2}, \mathrm{NO}_{\mathrm{x}}$ and many other pollutants, is a tradition for residents in Lhasa as well as ever increasing tourists who believe in Buddhism. Generally, the process of urbanization and commercialization in Lhasa has resulted in more severe $\mathrm{NO}_{2}$ pollution than $\mathrm{SO}_{2}$ pollution according to our measurements.

CO remained almost constant between 1998 and 2012, in contrast to the dramatically increased $\mathrm{NO}_{2}$. The more possible reason for a high CO level together with a very low $\mathrm{NO}_{2}$ level in 1998 might be the difference in the emission sources at the two sites in different years. Biomass burning was dominant in 1998, while fossil-fuel burning is dominant now. On average, there was no apparent diurnal cycle of CO in Lhasa in summer 1998. Nighttime CO mixing ratios were about $500 \mathrm{ppb}$, nearly 1.7 times of that during the daytime. However, distinct double peaks of $\mathrm{CO}$ mixing ratios in the morning and evening were observed in summer 2012 as shown in Fig. 5. The differences in the average diurnal variations of CO mixing ratios between 1998 and 2012 revealed an average increase in the rush hours reaching up to about $180 \mathrm{ppb}$, while a decrease to the same extent at night where a large variability of CO mixing ratios in summer 2012 was also found (Fig. 7a). During the daytime, $\mathrm{CO}$ mixing ratios in summer 1998 were almost level with that in summer 2012. Such changes in the observed diurnal cycles of CO mixing ratios probably suggest increased $\mathrm{CO}$ emissions from automobiles in the rush hours. Unfortunately, diurnal cycles of $\mathrm{NO}_{\mathrm{x}}$ mixing ratios in 1998 were not available to further confirm above conclusion.

A further examination of the $\mathrm{SO}_{2} / \mathrm{CO}, \mathrm{NO}_{\mathrm{x}} / \mathrm{CO}$, and $\mathrm{SO}_{2} / \mathrm{NO}_{\mathrm{x}}$ ratios was performed to cast more light on emission sources of the primary gases. Reduced major axis regression of the hourly average data was employed to account for measurement errors of each trace gas. It was found that the correlation coefficients $(R)$ of $\mathrm{SO}_{2}$ with $\mathrm{CO}$ and $\mathrm{SO}_{2}$ with $\mathrm{NO}_{\mathrm{x}}$ were above 0.9 in a significant level $(P<0.001)$ in autumn and winter 2012, while in spring less than 0.7 and in summer less than 0.4 (Fig. 8a and c). In contrast, $\mathrm{NO}_{\mathrm{x}}$ and $\mathrm{CO}$ mixing ratios were well correlated ( $R$ was 0.83 , $0.77,0.92,0.95$, respectively, in spring, summer, autumn and winter) throughout the year (Fig. 8b). The good correlations among primary gas pollutants in autumn and winter suggested common sources of $\mathrm{SO}_{2}, \mathrm{NO}_{\mathrm{x}}$ and $\mathrm{CO}$ in cold seasons, when the emission from coal burning for heating was thought to be the major source of primary gas pollutants in Lhasa. The poor correlations of $\mathrm{SO}_{2}$ with both $\mathrm{NO}_{\mathrm{x}}$ and $\mathrm{CO}$ in spring and especially in summer, as well as the rather low $\mathrm{SO}_{2}$ mixing ratios compared with that in cold seasons, 
(a)

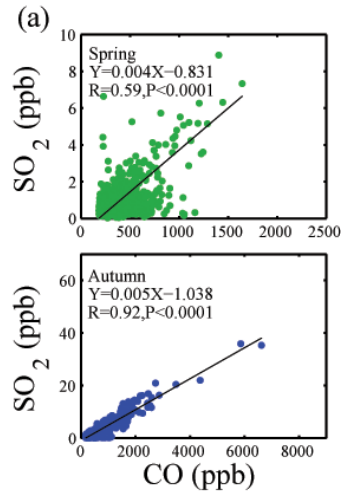

(c)
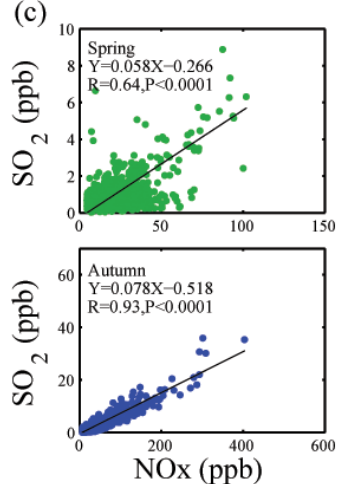
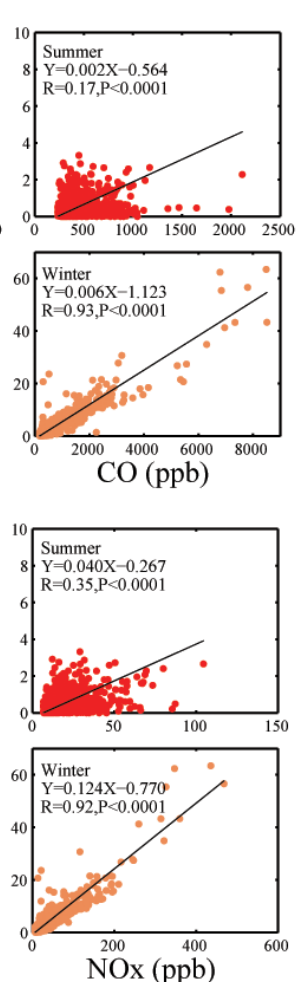

(b)
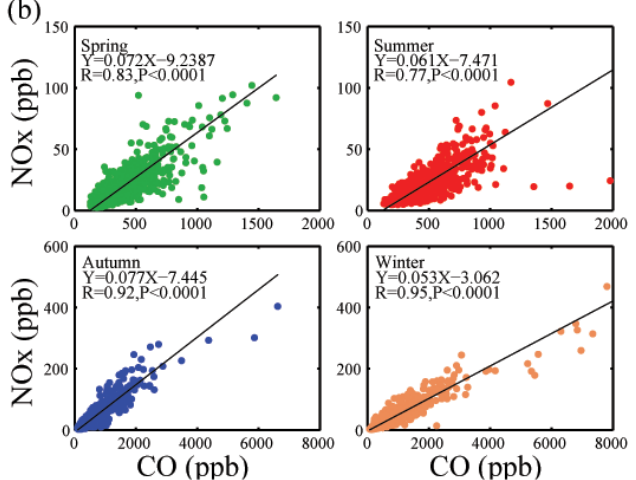

(d)
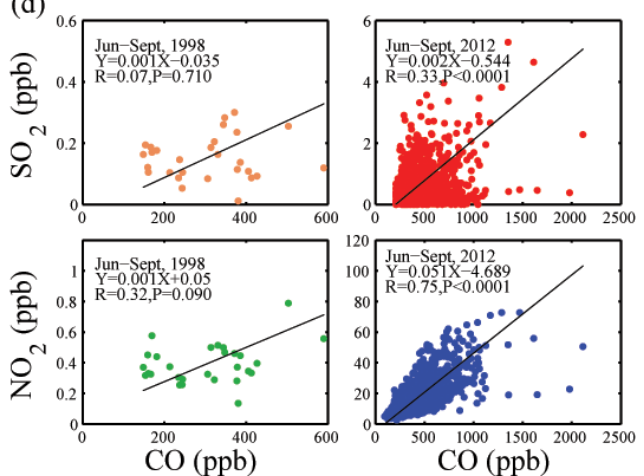

Figure 8. Reduced major axis regression of (a) $\mathrm{SO}_{2}$ versus $\mathrm{CO}$; (b) $\mathrm{NO}_{\mathrm{x}}$ versus $\mathrm{CO}$; (c) $\mathrm{SO}_{2}$ versus $\mathrm{NO}_{\mathrm{x}}$ in the four seasons during 2012 and 2013 in Lhasa using hourly average data. (d) Reduced major axis regression of $\mathrm{SO}_{2}$ versus $\mathrm{CO}$ and $\mathrm{NO}_{2}$ versus $\mathrm{CO}$ during June and September, respectively, in 1998 and 2012 in Lhasa.

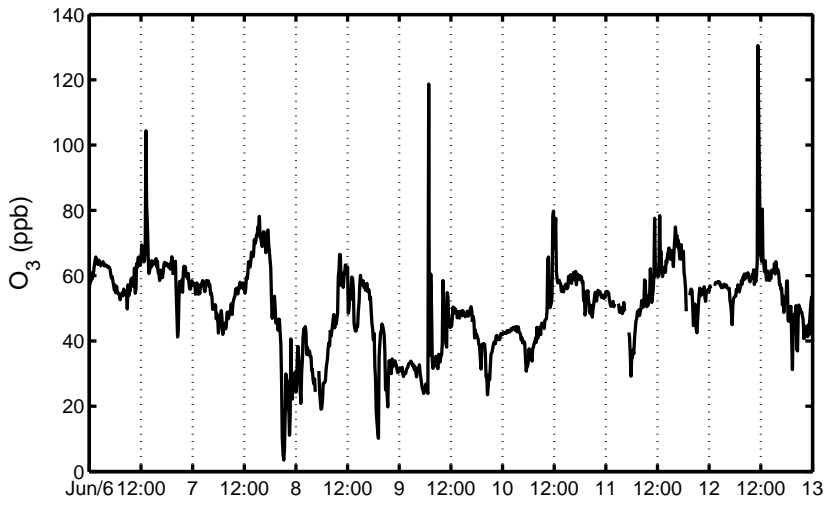

Figure 9. High ozone spikes around the noon during 6 and 13 June 2012 in Lhasa.

indicated that the major source of $\mathrm{SO}_{2}$ was different from that of $\mathrm{CO}$ and $\mathrm{NO}_{\mathrm{x}}$, which were mainly from gasoline and biomass burning in warm seasons. Besides, the far more efficient wet deposition of $\mathrm{SO}_{2}$ than $\mathrm{CO}$ and $\mathrm{NO}_{\mathrm{x}}$ in rainy spring and summer could also partially explain lower correlation coefficients of $\mathrm{SO}_{2}$ with $\mathrm{CO}$ and $\mathrm{SO}_{2}$ with $\mathrm{NO}_{\mathrm{x}}$ in spring and summer than in autumn and winter. Figure $8 \mathrm{~d}$ shows the scatter plots of $\mathrm{SO}_{2}$ versus $\mathrm{CO}$ and $\mathrm{NO}_{2}$ versus $\mathrm{CO}$ during June and September in 1998 and 2012. As indicated by the low $R$ value and the large $P$ value, no significant correlations were found between $\mathrm{SO}_{2}, \mathrm{NO}_{2}$ and $\mathrm{CO}$ in 1998, which was consistent with biomass to be the major source of the primary gas pollutants at that time. With the usage of fossil fuels and increasing consumptions, the mixing ratios of $\mathrm{SO}_{2}, \mathrm{NO}_{2}$ and $\mathrm{CO}$ increased dramatically and correlated more significantly with each other.

In response to increasing precursor emissions, the secondary gas pollutant $\mathrm{O}_{3}$ generally experienced an enhancement in summer in Lhasa (Fig. 7b and c). The average increments of $\mathrm{O}_{3}$ mixing ratios from the June-September 1998 period to the June-September 2012 period were, respectively, about 10, 6, 23, $14 \mathrm{ppb}$ in the afternoon (12:00 17:00 LT), which is the most productive period for $\mathrm{O}_{3}$ photochemical formation during a day. The buildup of $\mathrm{O}_{3}$ before the daily maximum in the afternoon (around 14:00 LT) was more efficient in summer 2012 than in summer 1998, accompanied by a higher level of $\mathrm{O}_{3}$ peak in summer 2012. This may imply a larger contribution is now made by $\mathrm{O}_{3}$ photochemical formation to the ambient $\mathrm{O}_{3}$ mixing ratios in the daytime, especially around the noon, compared to the condition several years ago. With increasing $\mathrm{O}_{3}$ precursor emissions and sufficient ultraviolet radiation in this area, more attention should be given to $\mathrm{O}_{3}$ photochemistry in the future. Averagely, an increase in nighttime $\mathrm{O}_{3}$ mixing ratios 
provided an evidence of elevated $\mathrm{O}_{3}$ background in this region, implying strengthened atmospheric oxidizing capacity in Lhasa. However, significant local emissions of NO and $\mathrm{NO}_{2}$ from vehicular exhaust and incense burning occasionally resulted in almost complete consumption of surface nighttime $\mathrm{O}_{3}$.

It was also worth noting that high $\mathrm{O}_{3}$ spikes in short duration (within $1 \mathrm{~h}$ ) were observed around the noon in June 2012 as shown in Fig. 9, while none in summer 1998. After excluding the possibility of an artifact being introduced by the instrument, it was believed that those high $\mathrm{O}_{3}$ spikes were probably an indicator of highly spatial inhomogeneity in air pollution in Lhasa, and as a result of polluted air parcels experiencing active $\mathrm{O}_{3}$ photochemical production and happening to pass by the site. This phenomenon can also be found in other seasons. High $\mathrm{O}_{3}$ basically came from the west, occurred after a violent wind shift and the following small wind, calm wind stage. Sometimes, an increase in CO mixing ratios could also be observed when an $\mathrm{O}_{3}$ spike appeared. This suggested a strong photochemical origin of $\mathrm{O}_{3}$. To thoroughly investigate this issue, especially the cause of the large $\mathrm{O}_{3}$ difference, more measurements and analysis need to be carried out in the future.

\section{Summary}

Various gas pollutants including $\mathrm{O}_{3}, \mathrm{NO}_{\mathrm{x}}, \mathrm{CO}$, and $\mathrm{SO}_{2}$ were continuously measured from June 2012 to May 2013 at an urban site in Lhasa, Tibet. The seasonal variations of $\mathrm{O}_{3}$ and $\mathrm{O}_{x}$ displayed a low valley in winter and a peak in spring, when the meteorology favored $\mathrm{O}_{3}$ photochemical production. The maximum monthly mean mixing ratios of $\mathrm{O}_{3}$ and $\mathrm{O}_{\mathrm{x}}$ were observed in May as $56.8 \pm 10.1 \mathrm{ppb}$ and $70.1 \pm 10.6 \mathrm{ppb}$, respectively. The independence of $\mathrm{O}_{3}$ mixing ratios on wind speed and wind direction in spring and summer suggested an important role of photochemistry in the observed mixing ratios of this secondary pollutant, while in autumn and winter, the transport process made a major contribution, showing increased $\mathrm{O}_{3}$ mixing ratios under larger wind speed. Generally, $\mathrm{O}_{3}$ mixing ratios in the $\mathrm{SW}-\mathrm{NW}$ sector were nearly $10 \mathrm{ppb}$ higher than that in other directions in autumn and winter. The diurnal cycle of $\mathrm{O}_{3}$ mixing ratios averagely exhibited a shallow flat peak for about $4-5 \mathrm{~h}$ in the afternoon and a minimum in the early morning throughout the year.

Mixing ratios of primary gas pollutants peaked from November to January with a large variability as $2.72 \pm 2.05 \mathrm{ppb}$ for $\mathrm{SO}_{2}, \quad 570 \pm 300 \mathrm{ppb}$ for $\mathrm{CO}$ and $29.58 \pm 16.16 \mathrm{ppb}$ for $\mathrm{NO}_{\mathrm{x}}$. In the rest of the year, $\mathrm{SO}_{2}$, $\mathrm{CO}$, and $\mathrm{NO}_{\mathrm{x}}$ averaged $0.77 \pm 0.61 \mathrm{ppb}, 363 \pm 94 \mathrm{ppb}$ and $17.10 \pm 6.19 \mathrm{ppb}$, respectively. A sharp decrease in the mixing ratios of primary trace gases was observed when wind speed increased. A slight dependence of trace gas mixing ratios on wind direction was found only under low wind speed. This implied local emissions of primary gas pol- lutants to be predominant in Lhasa. Diurnally, pronounced double peaks could be clearly identified in all seasons, as a result of enhanced traffic emissions in the rush hours as well as the diurnal variations of the boundary layer. Nighttime mixing ratios of primary gases were particularly high in autumn and winter when calm conditions usually happened. Under such circumstances, surface $\mathrm{O}_{3}$ could sometimes be totally consumed by the high level of NO.

A comparison has been made for measured $\mathrm{NO}_{2}, \mathrm{SO}_{2}$, $\mathrm{CO}$, and $\mathrm{O}_{3}$ from June to September between 1998 and 2012, in order to investigate the impact of rapid urbanization on air pollution in Lhasa. Mixing ratios of $\mathrm{NO}_{2}$ and $\mathrm{SO}_{2}$ have greatly increased in the past 15 years, due to a marked increase in their emissions. This was resulted from a substantial growth in the demand of energy consumption in the city and a change in using fossil fuels instead of biomass, which was also supported by the correlations among the primary gas pollutants. The distinct double-peak diurnal cycle of CO observed in summer 2012 reasonably indicated the major emission source for primary gas pollutants to be vehicular exhaust, given that there was no apparent diurnal cycle in summer 1998. In response to increased precursor emissions in the process of urbanization, there was a more efficient buildup of $\mathrm{O}_{3}$ mixing ratios in the morning and a higher peak in the afternoon in summer 2012 than in summer 1998. An enhancement in $\mathrm{O}_{3}$ mixing ratios would be expected in the photochemically active atmosphere with the ever increasing $\mathrm{O}_{3}$ precursor emissions. Therefore, measures should be taken to control emissions of primary gas pollutants in very near future in Lhasa, in order to reduce the occurrence of primary gas pollution events and mitigate the ozone problem.

Acknowledgements. This research was funded by the National Natural Science Foundation of China (21177157), the China Special Fund for Meteorological Research in the Public Interest (GYHY201106023) and the Basic Research Fund of CAMS (2011Z003). We also thank Prof. Tang Jie for providing the observational data in summer 1998.

Edited by: H. Su

\section{References}

Bian, J. C., Pan, L. L., Paulik, L., Vömel, H., Chen, H. B., and Lu, D. R.: In situ water vapor and ozone measurements in Lhasa and Kunming during the Asian summer monsoon, Geophys. Res. Lett., 39, L19808, doi:10.1029/2012GL052996, 2012.

Bishop, G. A., Morris, J. A., Stedman, D. H., Cohen, L. H., Countess, R. J., Countess, S. J., Maly, P., and Scherer, S.: The effects of altitude on heavy-duty diesel truck on-road emissions, Environ. Sci. Technol., 35, 1574-1578, 2001.

Chaffin, C. and Ullman, T.: Effects of increased altitude on heavyduty diesel engine emissions, SAE Technical Paper 940669, doi:10.4271/940669, 1994. 
Chameides, W. L., Kasibhatla, P. S., Yienger, J., and Levy II, H.: Growth of Continental-Scale Metro-Agro-Plexes, regional ozone pollution, and world food production, Science, 264, 7477, doi:10.1126/science.264.5155.74, 1994.

Dechen, D., Norbu, T., and Mima, P.: Correlative analysis on relationship between changes of several main contaminations and some meteorological elements in Lhasa urban area, J. Tibet Uni., 23, 7-11, 2008.

Guo, D., Wang, P. X., Zhou, X. J., Liu, Y., and Li, W. L.: Dynamic effects of the South Asian high on the ozone valley over the Tibetan Plateau, Acta. Meteo. Sinica, 26, 216-228, 2012.

Haagen-Smit, A. J.: Chemistry and Physiology of Los Angeles Smog, Ind. Eng. Chem., 44, 1342-1346, 1952.

Haagen-Smit, A. J., Bradley, C. E., and Fox, M. M.: Ozone formation in photochemical oxidation of organic substances, Ind. Eng. Chem., 45, 2086-2089, doi:10.1021/ie50525a044, 1953.

He, K., Huo, H., and Zhang, Q.: Urban air pollution in China: current status, characteristics, and progress, Annual Rev. Energy Environ., 27, 397-431, 2002.

Jacobson, M. Z.: Atmospheric pollution: history, science and regulation, Cambridge University Press, New York, 399 pp., 2002.

Lei, W., Zavala, M., de Foy, B., Volkamer, R., and Molina, L. T.: Characterizing ozone production and response under different meteorological conditions in Mexico City, Atmos. Chem. Phys., 8, 7571-7581, doi:10.5194/acp-8-7571-2008, 2008.

Lin, W., Zhu, T., Song, Y., Zou, H., Tang, M., Tang, X., and Hu, J.: Photolysis of surface $\mathrm{O}_{3}$ and production potential of $\mathrm{OH}$ radicals in the atmosphere over the Tibetan Plateau, J. Geophys. Res., 113, D02309, doi:10.1029/2007JD008831, 2008.

Lin, W., Xu, X., Ge, B., and Zhang, X.: Characteristics of gaseous pollutants at Gucheng, a rural site southwest of Beijing, J. Geophys. Res., 114, D00G14, doi:10.1029/2008JD010339, 2009.

Lin, W., Xu, X., Ge, B., and Liu, X.: Gaseous pollutants in Beijing urban area during the heating period 2007-2008: variability, sources, meteorological, and chemical impacts, Atmos. Chem. Phys., 11, 8157-8170, doi:10.5194/acp-11-8157-2011, 2011.

Lin, W. L., X. B. Xu, Z. Q. Ma, Zhao, H. R., Liu, X. W., and Wang, Y.,: Characteristics and recent trends of sulfur dioxide at urban, rural, and background sites in North China: Effectiveness of control measures, J. Environ. Sci., 24, 34-49, doi:10.1016/S10010742(11)60727-4, 2012.

Liu, Y., Li, W. L., Zhou, X. J., and He, J. H.: Mechanism of formation of the ozone valley over the Tibetan Plateau in summer transport and chemical process of ozone, Adv. Atmos. Sci., 20, 103-109, 2003.

Ma, J., Lin, W. L., Zheng, X. D., Xu, X. B., Li, Z., and Yang, L. L: Influence of air mass downward transport on the variability of surface ozone at Xianggelila Regional Atmosphere Background Station, southwest China, Atmos. Chem. Phys., 14, 5311-5325, doi:10.5194/acp-14-5311-2014, 2014.

Molina, M. J. and Molina, L. T.: Megacities and Atmospheric Pollution, 1. Air \& Waste Manage. Assoc., 54, 644-680, 2004.

Monks, P. S.: A review of the observations and origins of the spring ozone maximum, Atmos. Environ., 34, 3545-3561, 2000.

Nagpure, A. S., Burjar, B. R., and Kumar, P.: Impact of altitude on emission rates of ozone precursors from gasoline-driven lightduty commercial vehicles, Atmos. Environ., 45, 1413-1417, 2011.
Norsang, G., Kocbach, L., Tsoja, W., Stamnes, J. J., Dahlback, A., and Nema, P.: Ground-based measurements and modeling of solar UV-B radiation in Lhasa, Tibet, Atmos. Environ., 43, 14981502, 2009.

$\mathrm{Pu}$ Bu, C. R., Sigernes, F., and Gjessing, Y.: Ground-based measurements of solar ultraviolet radiation in Tibet: Preliminary results, Geophys. Res. Lett., 24, 1359-1362, doi:10.1029/97GL01319, 1997.

Ren, P. B. C., Gjessing, Y., and Sigernes, F.: Measurements of solar ultraviolet radiation on the Tibetan Plateau and comparisons with discrete ordinate method simulations, J. Atmos. Sol. Terr. Phys., 61, 425-446, 1999.

Seinfeld, J. H. and Pandis, S. N.: Atmospheric Chemistry and Physics: from Air Pollution to Climate Change, Wiley Interscience, New Jersey, 1225 pp., 2006.

Shi, G. Y., Bai, Y. B., Iwasaka, Y., and Ohashi, T.: A balloon measurement of the ozone vertical distribution over Lhasa, Adv. Earth Sci., 15, 522-524, 2000.

Stephens, S., Madronich, S., Wu, F., Olson, J. B., Ramos, R., Retama, A., and Munoz, R.: Weekly patterns of Mexico City's surface mixing ratios of $\mathrm{CO}, \mathrm{NO}_{\mathrm{x}}, \mathrm{PM}_{10}$ and $\mathrm{O}_{3}$ during 19862007, Atmos. Chem. Phys., 8, 5313-5325, doi:10.5194/acp-85313-2008, 2008.

Tang, J., Zhou, L. X., Zheng, X. D., Zhou, X. J., Shi, G. Y., and Suolang, D. J.: The observational study of surface ozone at Lhasa suburb in summer 1998, Act. Meteo. Sinica, 60, 221-229, 2002.

Tang, Q. and Prather, M. J.: Tropospheric column ozone: matching individual profiles from Aura OMI and TES with a chemistry-transport model, Atmos. Chem. Phys., 12, 1044110452, doi:10.5194/acp-12-10441-2012, 2012.

Tsering, P., Nima, Y., and Lhak, P.: Analysis of urban heat island effect in Lhasa city, Plat. Mount. Meteorol. Res., 34, 52-56, 2014.

Tobo, Y. Iwasaka, Y., Shi, G. Y., Kim, Y. S., Tamura, K., and Ohashi, T.: Summertime "ozone valley" over the Tibetan Plateau derived from ozonesondes and EP/TOMS data, Geophys. Res. Lett., 35, L16801, doi:10.1029/2008GL034341, 2008.

USEPA: Quality Assurance Handbook for Air Pollution Measurement Systems, Volume II, Ambient Air Quality Monitoring Program, EPA-454/B-08-003, 2008.

Xu, W. Y., Zhao, C. S., Ran, L., Deng, Z. Z., Liu, P. F., Ma, N., Lin, W. L., Xu, X. B., Yan, P., He, X., Yu, J., Liang, W. D., and Chen, L. L.: Characteristics of pollutants and their correlation to meteorological conditions at a suburban site in the North China Plain, Atmos. Chem. Phys., 11, 4353-4369, doi:10.5194/acp-114353-2011, 2011.

Yu, X. L., Tang, J., Zhou, L. X., Xue, H. S., and Zhou, X. J.: Emission characteristics and sources of non-methane hydrocarbons at Lhasa Area, Act. Sci. Circum., 21, 203-207, 2001.

Zhou, L. X., Tang, J., Yu, X. L., Lam, K., Xue, H. S., Shi, G. Y, and Zhou, X. J.: Preliminary investigation of atmospheric CO, $\mathrm{SO}_{2}$ and $\mathrm{NO}_{2}$ variation in Lhasa area during summer time, Res. Environ. Sci., 14, 16-23, 2001. 